\title{
Morphological, Physical and Chemical Characteristics of Hill Forest Soils at Chittagong University, Bangladesh
}

\author{
Md. Akhtaruzzaman", Md. Enamul Haque, Khan Towhid Osman
}

Department of Soil Science, University of Chittagong, Chittagong, Bangladesh.

Email: *akhtarcu@yahoo.com

Received December $9^{\text {th }}, 2013$; revised January $9^{\text {th }}, 2014$; accepted January $17^{\text {th }}, 2014$

Copyright (c) 2014 Md. Akhtaruzzaman et al. This is an open access article distributed under the Creative Commons Attribution License, which permits unrestricted use, distribution, and reproduction in any medium, provided the original work is properly cited. In accordance of the Creative Commons Attribution License all Copyrights @ 2014 are reserved for SCIRP and the owner of the intellectual property Md. Akhtaruzzaman et al. All Copyright (c) 2014 are guarded by law and by SCIRP as a guardian.

\section{ABSTRACT}

Forty five soil samples were collected from the four pedons of the hill areas at Chittagong University based on the depth of soil horizon. Soil profiles on hill top were relatively well developed and belonged to Ultisols according to USDA soil Taxonomy. The profiles at the piedmont were relatively young soils and classified as Inceptisols and Entisols. The soils of all profiles were characterized by coarse texture ( $38 \%$ to $73 \%$, sand fraction), high bulk density (1.15 to $1.32 \mathrm{Mg} \cdot \mathrm{m}^{-3}$ ), low organic-C content $\left(0.26 \%\right.$ to $1.73 \%$ ), acid soil reaction ( $\mathrm{pH}_{\mathrm{H}_{2} \mathrm{O}}$ varied from 4.44 to 5.52 and $\mathrm{pH}_{\mathrm{KCl}}$ from 3.57 to 4.90). Soils in all pedons were poor in exchangeable bases and base saturation. The CEC values ranged from 9.12 cmolc $\cdot \mathrm{kg}^{-1}$ to $14.5 \mathrm{cmolc} \cdot \mathrm{kg}^{-1}$ while ECEC varied from 1.96 to 4.78 $\mathrm{cmolc} \cdot \mathrm{kg}^{-1}$. The exchangeable Al (aluminum) concentration ranged from 0.41 to $0.66 \mathrm{cmolc}^{-1} \mathrm{~kg}^{-1}$. Exchangeable acidity level ranged from 0.74 to $1.25 \mathrm{cmolc} \mathrm{kg}^{-1}$. Exchangeable Al and aluminum saturation increased with depth and their concentrations were below the toxic range for tree stands. The study revealed that more young soils formed on the piedmont sites had somewhat better properties as compared to matured hill top soils. The variation in physico-chemical properties of the soils seemed to be influenced by the topography to a greater extent in the studied area.

\section{KEYWORDS}

\section{Soil Morphological Features; Soil Physico-Chemical Properties; Soil Classification}

\section{Introduction}

The differences in soil characteristics associated with landscape position are usually attributed to differences in the runoff, erosion and deposition processes which affect soil genesis [1-4].

The investigation area comprising of low hill soils is mainly underlain by little consolidated sandstone and shale of Dupi Tila formation probably of mid Miocene to Pliocene age [5]. These are well-drained strong brown, strongly structured, deep acid soils and low to moderately fertile. These soils unless hindered by lateritic formation, plinthitic concretions at shallow depth, are suitable for a wide range of forest tree species, horticultural species, and industrial plantations e.g. rubber, tea, systematic orchards etc. [6].

\footnotetext{
"Corresponding author.
}

The hill soils under study mainly occurred on hill summits and piedmont soils under a good cover of vegetations. The degree of surface runoff and soil erosion is mainly related to land physiography and slope gradients.

The variation in soil properties might be attributed to topographical variations of hill soils. A broad landscape with gentle slopes will permit rapid vertical movement of water through soil. Such level landscape will have thick soil profiles and well developed horizons. This is a consequence of enhanced infiltration and strong vertical fluxes of water leading to greater rates of soil profile development, and some deposition of material eroded from adjacent, steeper slopes. In more steeply sloping landscapes, particularly on shoulders and back slopes, increased rates of erosion and runoff and decreased vertical percolation of water will lead to thin and weakly 
developed soils [7]. Furthermore, landscape morphology and topography also affected the distribution of soil properties and soil nutrient status in forested soils [8].

However, most of the previous studies have emphasized the growth performance of planted species along with the planting technique in the above areas with less concern on the soil characteristics which are important in context of adopting some strategies for improving and maintaining soil resources.

Study on soil characteristics in particular morphological, physico-chemical properties will provide basic information for better plant growth and management of the soil resources. Hill soils of Bangladesh are acidic in nature [5]. Higher topography enhances the removal base cations through leaching and runoff processes and forest hill soils become gradually acidified.

The hill soils face severe degradation due to intensive leaching, soil acidification, biotic activity, and improper land use systems. Such processes play their pertinent roles and influence the rate of weathering and the kind of weathering products in the hilly region.

The acidification of soils leads not only to $\mathrm{pH}$ decreasing, but also to leaching of base cations and increasing $\mathrm{Al}^{3+}$ concentrations [9]. Acid forest soils often develop high levels of soluble aluminum. In fact, the more acidified a soil is, the more aluminum rich clay particles will release $\mathrm{Al}$ into solution [10].

In acid soils, the content of mobile $\mathrm{Al}$ is rather high. Simultaneously, there is an increase in the uptake of this element by plants which cause damage to roots and a decrease in the uptake of other nutrient elements [11].

The form of Al plays a decisive role in its potential bioavailability and toxicity. Aluminium bound in fluoride or organic complexes and $\mathrm{Al}(\mathrm{OH})_{3}$ are supposed to be non-toxic [12-14]. The complexation of Al by natural organic substances is of considerable significance in regulating concentrations of the highly toxic $\mathrm{Al}^{3+}$ ion in acid soils [13].

Little information is available on the effect of landscape and topography on soil morphology and other soil properties in forested hill soils in Bangladesh, particularly in areas of Chittagong University.

Considering the fact, the objective of this study was therefore to evaluate some morphological, physical and chemical characteristics of hill forest soils at different topographical level. This study also provides useful information that can be used as a guideline for soil management and forest rehabilitation at the investigated area.

\section{Materials and Methods}

\subsection{Site Description}

The study area is located at planted forest on the hills of Chittagong University and ranged in elevation from 11 to $48 \mathrm{~m}$ above mean sea level (Table 1). The climate of the study area is warm (sub-tropical) with a mean annual air temperature of $25.7^{\circ} \mathrm{C}$, a mean annual precipitation of $2735 \mathrm{~mm}$ and potential total evaporation of $1427 \mathrm{~mm}$. The soil moisture regime is udic and soil temperature regime is isohyperthermic [15]. The study area is predominantly covered with different types of tree species, herbs and shrubs.

In this study, four soil profiles formed on different elevation of hill forests were investigated. The physiography of the investigated area comprises hill summit, upper piedmont and lower piedmont. Two profiles were dug on hill summit: one hill summit site was narrow landscape with gently sloping to moderately sloping and another hill summit had broad and flat landscape (Table 1). The profiles were also opened at higher piedmont and lower piedmont.

At each site, soil samples were collected in triplicates from different successive horizons using a scoop. A total of 45 soil samples ( 3 replicates $\times 15$ horizons) were collected for analysis.

The morphological properties of the profiles were described during soil samples collection in the field using the criteria of the soil survey manual of soil survey division staff [16] and the guidelines for soil profile description [17].

In addition, core samples were also taken by using bulk density corer from the center of each horizon for soil density analysis.

The undisturbed soil samples were packed in precleaned air tight plastic bags labeled and transferred to the laboratory for further processing and analysis.

Table 1. Physical environment of the studied areas.

\begin{tabular}{ccccccc}
\hline Profile no. & Land use & Parent material & Age & $\begin{array}{c}\text { Elevation } \\
\text { (m above MSL) }\end{array}$ & $\begin{array}{c}\text { Physiography } \\
\text { (Nature of landscape) }\end{array}$ & Slope (\%) \\
\hline Profile I & Forest & Tertiary rock & Tertiary & 48 & Hill summit (narrow) & $4-15$ \\
Profile II & Forest & Tertiary rock & Tertiary & 39 & Hill summit (broad) & $1-2$ \\
Profile III & Forest & Hill sediment & Young & 20 & Upper piedmont (broad) & 4 \\
Profile IV & Forest & Hill sediment & Recent & 11 & Lower piedmont (broad) & 2 \\
\hline
\end{tabular}

MSL_Mean sea level. 


\subsection{Laboratory Analysis}

The soil samples were air dried ground and screened using a $2 \mathrm{~mm}$ sieve. Particle size distribution of the soils was determined by hydrometer method [18]. Soil color was measured by Munsell soil color chart at both moist and dry conditions of soils. Bulk density was determined by the core method. Cation exchange capacity (CEC) was determined after extraction of the cations with ammonium acetate [19]. The $\mathrm{pH}_{\mathrm{H}_{2} \mathrm{O}}$ values were measured by mixing soil with deionized water at a ratio of 1:2.5 (soil: water) followed by shaking the suspension for $1 \mathrm{~h}$ and using corning glass electrode $\mathrm{pH}$-meter. The $\mathrm{pH}_{\mathrm{KCl}}$ of the soils was measured with corning glass electrode $\mathrm{pH}$-meter using a soil solution 1:2.5 (soil: $1 \mathrm{M} \mathrm{KCl}$ ) after shaking for $1 \mathrm{~h}$. Organic carbon was determined by wetoxidation method of Walkley-Black [20]. Available calcium, magnesium, potassium and sodium were extracted with $1 \mathrm{~N} \mathrm{NH}_{4} \mathrm{OAC}$ and determined by an atomic absorption spectrophotometer. Percent base saturation (PBS) was calculated using the formula BS\% $=[(\Sigma$ of exch. $\mathrm{Ca}$, $\mathrm{Mg}, \mathrm{K}$, and $\mathrm{Na}) / \mathrm{CEC}] \times 100$.

Exchangeable acidity was determined by titration of $25 \mathrm{ml} \mathrm{KCl}$ extract with $0.5 \mathrm{~N} \mathrm{NaOH}$, using $0.1 \%$ phenolphthalein indicator (titration from colorless to pink). Then, the concentration of exchangeable $\mathrm{Al}^{3+}$ was ob- tained by back-titration of the same $\mathrm{KCl}$ extract, previously used, after the acidification with a drop of $\mathrm{HCl}$ and addition of $4 \% \mathrm{NaF}$, with $0.5 \mathrm{~N} \mathrm{HCl}$ (titration from pink to colorless).

The effective cation exchange capacity (ECEC) was calculated as the sum of exchangeable $\mathrm{Ca}, \mathrm{Mg}, \mathrm{K}, \mathrm{Na}$ and exchangeable acidity $\left(\mathrm{Al}^{3+}+\mathrm{H}^{+}\right)$. Percent Aluminum saturation (Als) was calculated using the formula: Als (\%) $=($ exchangeable $\mathrm{Al} / \mathrm{ECEC}) \times 100$.

The horizons from each profile were condensed into surface and subsurface soils for statistical analysis. A and E horizons of profile I and profile II were considered as surface layers and $\mathrm{Bt}$ as subsurface layers. For profile III, A and Bw1 + Bw2 were regarded as surface and subsurface layers, for profile IV, A and C1 as surface and subsurface layers respectively. Statistical analyses were done by using Minitab program [21].

\section{Results and Discussion}

\subsection{Soil Morphological Properties and Soil Classification}

Clay fraction tended to increase with depth in both profiles I and profile II upto B horizon, except the C horizon (Table 2). In both profiles, the illuvial B horizons were

Table 2. Some soil physical properties of profiles.

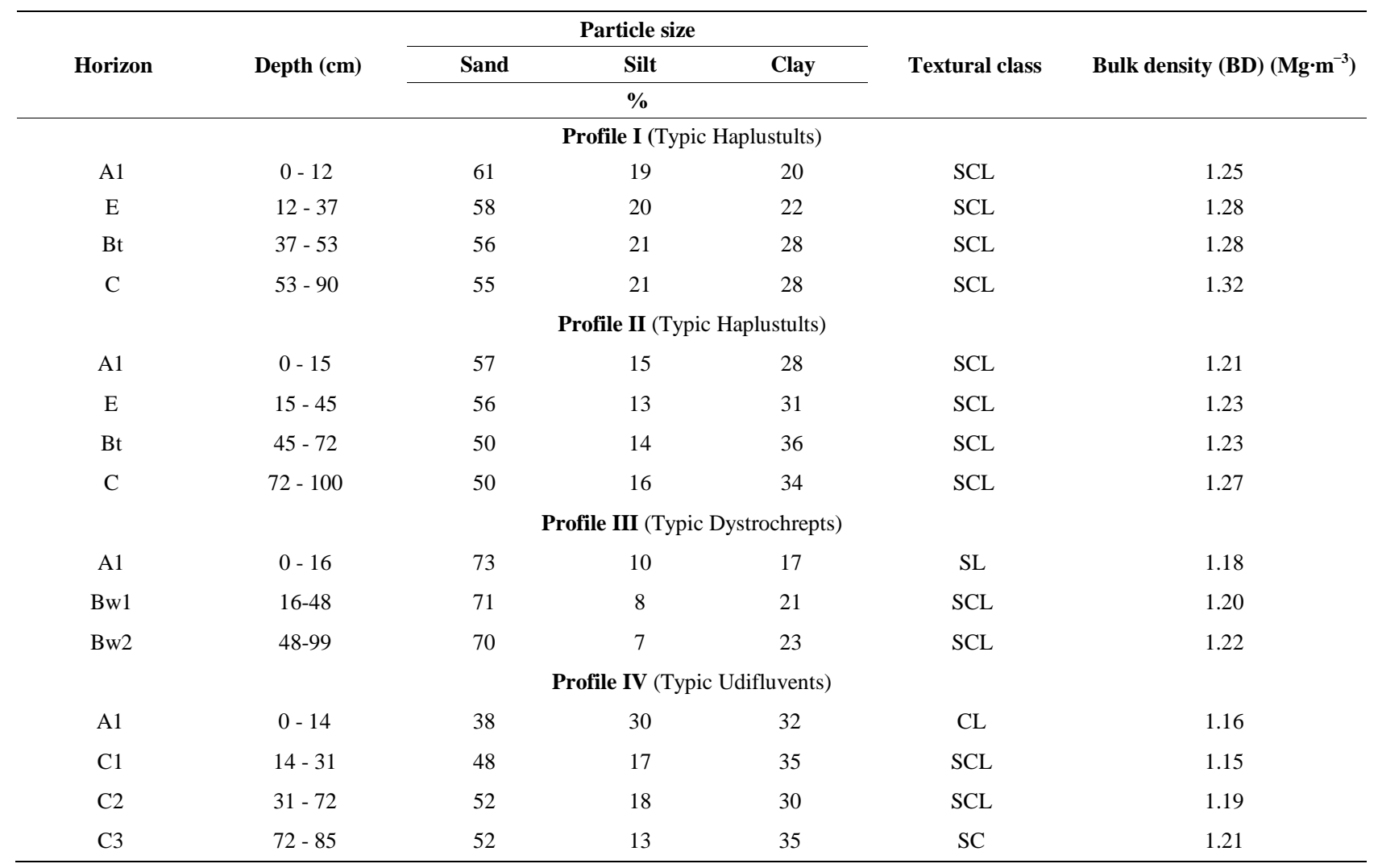

SCL—Sandy clay loam, SL—Sandy loam, CL—Clay loam, SC—Sandy clay. 
characterized by argillic horizon with the evidence of clay films on ped surfaces (clay cutans). Due to clay eluviation (movement of clay from upper horizons), clay accumulation was observed between 37 and $53 \mathrm{~cm}$ depth for profile I and between 45 and $72 \mathrm{~cm}$ depth for profile II. Between these depths, clay cutans were also observed. This may be an indication of the translocation of clays from the surface downward by argilluviation process. Boul and Hole [22] stated that an argillic horizon must contain a minimum clay increase relative to the eluvial horizon or an underlying horizon, and show evidence of clay movement. On the other hand, the soils had the low base saturation $(<35 \%)$ and cation exchange capacity (Table 3). Thus the soils were grouped into the order Ultisols. In addition, the soils were characterized by presence of plinthite (less than 50 percent), high contents of Fe and $\mathrm{Mn}$ concretions and gravels, hence they belonged to the great group Hapludults. Consequently soils were classified at subgroup level as Typic Hapludults and orthi-Haplic Alisols as per Soil Survey Staff [23] and FAO/ISRIC [24].

There was a substantial increase in clay content in the lower horizons of profile III (Table 2). The soils at the above sites failed argillic horizon requirement of clay skin evidences on ped surfaces during profile study. Moreover, the soil structure of the profile was poorly developed (weak fine or medium angular blocky) in nature at the surface coming down to relatively well developed (moderate or strong medium or coarse angular blocky) at the subsoil (Table 4). Thus the illuvial horizons with stronger structure supported more the characteristics of cambic horizons than that of argillic horizons. So, the soils were classified as the order Inceptisols. Profile III included the A horizon with low color value and low chroma. In addition, this horizon with organic material was too thin to meet the requirements of a mollic or umbric epipedon [23]. Moreover, soils had a low base saturation (by $\mathrm{NH}_{4} \mathrm{OAc}$ ) in all horizons of the profile.

Therefore, the profile at piedmont might be defined as young soils and classified at great group and sub group category as Dystrochrepts and Typic Dystrochrepts respectively [23] and Orthi-Dystric Cambisol [24].

In profile IV, Clay content increased with depth in the profile to such degree that was not enough to quantify subsoil as argillic horizon. In addition, soils of this site were relatively younger in age and parent material (hill sediment). The profile included the minimum horizons (A and $\mathrm{C}$ horizons) and it had the weak development of soil structure only in the surface A horizons (Table 4). There was no formation of soil structure had after this depth.

Table 3. Some soil chemical properties of profiles.

\begin{tabular}{|c|c|c|c|c|c|c|c|c|c|c|c|c|c|c|}
\hline \multirow{2}{*}{ Horizon } & \multirow{2}{*}{$\begin{array}{c}\text { Depth } \\
\text { (cm) }\end{array}$} & \multirow{2}{*}{ OC (\%) } & \multirow{2}{*}{$\mathbf{p} \mathbf{H}_{\mathrm{H}_{2} \mathrm{O}}$} & \multirow{2}{*}{$\mathbf{p H} \mathbf{K C l}$} & $\mathrm{Ca}^{2+}$ & $\mathrm{Mg}^{2+}$ & $\mathbf{K}^{+}$ & $\mathrm{Na}^{+}$ & \multirow{2}{*}{$\begin{array}{l}\text { PBS } \\
(\%)\end{array}$} & CEC & Ex. $\mathbf{A l}^{3+}$ & ECEC & \multirow{2}{*}{$\begin{array}{l}\text { Als } \\
(\%)\end{array}$} & \multirow{2}{*}{$\begin{array}{l}\text { Ex. Acidity } \\
\left(\mathrm{cmolc}^{\prime} \mathrm{kg}^{-1}\right)\end{array}$} \\
\hline & & & & & \multicolumn{4}{|c|}{ cmolc $\cdot k^{-1}$} & & \multicolumn{3}{|c|}{$\mathrm{cmolc} \cdot \mathrm{kg}^{-1}$} & & \\
\hline \multicolumn{15}{|c|}{ Profile I (Typic Haplustults) } \\
\hline A1 & $0-12$ & 1.15 & 5.10 & 3.96 & 1.65 & 0.98 & 0.47 & 0.28 & 29.5 & 11.44 & 0.60 & 4.48 & 13.39 & 1.1 \\
\hline $\mathrm{E}$ & $12-37$ & 1.10 & 4.95 & 3.88 & 1.35 & 0.67 & 0.32 & 0.17 & 27.5 & 9.12 & 0.63 & 3.64 & 17.31 & 1.13 \\
\hline $\mathrm{Bt}$ & $37-53$ & 0.41 & 4.86 & 3.84 & 1.23 & 0.27 & 0.16 & 0.06 & 18.4 & 9.37 & 0.65 & 2.87 & 22.65 & 1.15 \\
\hline $\mathrm{C}$ & $53-90$ & 0.26 & 4.44 & 3.57 & 0.98 & 0.19 & 0.17 & 0.07 & 11.8 & 11.9 & 0.66 & 2.66 & 24.81 & 1.25 \\
\hline \multicolumn{15}{|c|}{ Profile II (Typic Haplustults) } \\
\hline A1 & $0-15$ & 1.54 & 5.16 & 4.15 & 1.89 & 1.12 & 0.53 & 0.32 & 32.7 & 11.8 & 0.54 & 4.78 & 11.30 & 0.92 \\
\hline $\mathrm{E}$ & $15-45$ & 1.31 & 5.11 & 4.12 & 1.53 & 0.89 & 0.44 & 0.26 & 30.7 & 10.17 & 0.59 & 4.1 & 14.39 & 0.98 \\
\hline $\mathrm{Bt}$ & $45-72$ & 0.54 & 4.91 & 4.10 & 1.43 & 0.33 & 0.21 & 0.22 & 23.0 & 9.54 & 0.61 & 3.29 & 18.54 & 1.10 \\
\hline $\mathrm{C}$ & $72-100$ & 0.33 & 4.68 & 3.82 & 1.20 & 0.29 & 0.3 & 0.19 & 16.2 & 12.2 & 0.62 & 3.11 & 19.94 & 1.13 \\
\hline \multicolumn{15}{|c|}{ Profile III (Typic Dystrochrepts) } \\
\hline A1 & $0-16$ & 1.61 & 5.17 & 4.23 & 1.66 & 1.10 & 0.45 & 0.30 & 32.5 & 10.8 & 0.48 & 4.4 & 10.91 & 0.89 \\
\hline Bw1 & $16-48$ & 1.36 & 5.12 & 4.59 & 1.64 & 0.57 & 0.39 & 0.28 & 29.8 & 9.67 & 0.52 & 3.82 & 13.07 & 0.94 \\
\hline Bw2 & $48-99$ & 0.41 & 5.12 & 4.13 & 1.30 & 0.34 & 0.28 & 0.22 & 23.0 & 9.3 & 0.55 & 3.19 & 16.87 & 1.05 \\
\hline \multicolumn{15}{|c|}{ Profile IV (Typic Udifluvents) } \\
\hline A1 & $0-14$ & 1.73 & 5.52 & 4.90 & 2.17 & 1.46 & 0.65 & 0.57 & 33.4 & 14.5 & 0.41 & 3.99 & 7.33 & 0.74 \\
\hline $\mathrm{C} 1$ & $14-31$ & 1.45 & 5.23 & 4.70 & 1.97 & 0.54 & 0.35 & 0.35 & 31.7 & 10.12 & 0.44 & 2.21 & 12.12 & 0.85 \\
\hline $\mathrm{C} 2$ & $31-72$ & 0.63 & 5.11 & 4.65 & 1.64 & 0.58 & 0.43 & 0.09 & 22.3 & 12.3 & 0.46 & 2.12 & 13.49 & 0.93 \\
\hline C3 & $72-85$ & 0.45 & 5.10 & 4.36 & 1.42 & 0.36 & 0.39 & 0.1 & 21.8 & 10.41 & 0.47 & 1.96 & 16.85 & 1.01 \\
\hline
\end{tabular}

OC_-Organic carbon, Als_-Aluminum saturation, CEC—Cation exchange capacity, ECEC—Effective cation exchange capacity, PBS—Percent base saturation, Ex. Al—Exchangeable Al, Ex. acidity—Exchangeable acidity. 
Table 4. Some morphological characteristics of profiles.

\begin{tabular}{|c|c|c|c|c|c|c|c|c|}
\hline Horizon $^{a}$ & $\begin{array}{l}\text { Depth } \\
\text { (cm) }\end{array}$ & Boundary $^{b}$ & $\begin{array}{l}\text { Colour } \\
\text { moist }\end{array}$ & $\begin{array}{c}\text { Colour } \\
\text { dry }\end{array}$ & Texture $^{c}$ & Structure $^{\mathrm{d}}$ & Consistency $^{e}$ & $\begin{array}{c}\text { Special } \\
\text { features }\end{array}$ \\
\hline \multicolumn{9}{|c|}{ Profile I (Typic Haplustults) } \\
\hline A1 & $0-12$ & CS & 10YR3/3 & 10YR3/6 & SCL & $1 \mathrm{fsbk}$ & sst.pl ${ }_{0}$. sfr.sh & \multirow{4}{*}{ cutans } \\
\hline E & $12-37$ & cs & 10YR5/4 & 10YR5/8 & SCL & $2 m s b k$ & sst.pl ${ }_{0} . s f r . s h$ & \\
\hline $\mathrm{Bt}$ & $37-53$ & ds & 10YR4/6 & 7.5YR5/6 & SCL & $2 \mathrm{msbk}$ & sst.pl.fr.sh & \\
\hline \multirow[t]{2}{*}{$\mathrm{C}$} & $53-90$ & - & 7.5YR5/6 & 7.5YR5/8 & SCL & $2 \mathrm{msbk}$ & sst.pl.fr.sh & \\
\hline & \multicolumn{7}{|c|}{ Profile II (Typic Haplustults) } & \multirow{5}{*}{$\begin{array}{c}\text { Crotovina } \\
\text { cutans }\end{array}$} \\
\hline $\mathrm{A} 1$ & $0-15$ & Cs & $10 \mathrm{YR} 4 / 4$ & 10YR5/4 & SCL & $1 \mathrm{msbk}$ & st. $\mathrm{pl}_{0} . \mathrm{fr} . \mathrm{sh}$ & \\
\hline $\mathrm{E}$ & $15-45$ & ds & $10 Y R 3 / 4$ & $10 \mathrm{YR} 4 / 2$ & SCL & $1 \mathrm{msbk}$ & sst. spl. sfr.sh & \\
\hline $\mathrm{Bt}$ & $45-72$ & ds & 10YR5/6 & 7.5YR5/6 & SCL & 2csbk & st.spl.fr.sh & \\
\hline \multirow[t]{2}{*}{$\mathrm{C}$} & $72-100$ & - & 10YR5/6 & 7.5YR5/8 & SCL & 3csbk & st.spl.fr.h & \\
\hline & \multicolumn{7}{|c|}{ Profile III (Typic Dystrochrepts) } & \multirow{4}{*}{ Fe staining } \\
\hline A1 & $0-16$ & CS & 10YR4/4 & 10YR5/6 & SL & ma & sst.spl.fr.sh & \\
\hline Bw1 & $16-48$ & CS & 10YR4/6 & 7.5YR4/6 & SCL & $1 \mathrm{msbk}$ & sst.spl.fr.sh & \\
\hline \multirow[t]{2}{*}{ Bw2 } & $48-99$ & - & 10YR3/6 & $10 \mathrm{YR} 5 / 4$ & SCL & $1 \mathrm{msbk}$ & sst.spl.fr.sh & \\
\hline & \multicolumn{7}{|c|}{ Profile IV (Typic Udifluvents) } & \multirow{5}{*}{$\begin{array}{l}\text { mottles } \\
\text { mottles } \\
\text { mottles }\end{array}$} \\
\hline A1 & $0-14$ & as & $10 \mathrm{YR} 4 / 2$ & 10YR4/6 & CL & 1 fgr & st.spl.fr.sh & \\
\hline C1 & $14-31$ & aw & $10 \mathrm{YR} 4 / 3$ & $7.5 Y R 4 / 3$ & SCL & $1 \mathrm{fsbk}$ & sst.spl.fr.sh & \\
\hline C2 & $31-72$ & $\mathrm{cw}$ & $10 \mathrm{YR} 3 / 3$ & 7.5YR4/4 & SCL & ma & sst.spl.fr.sh & \\
\hline C3 & $72-85$ & - & $10 \mathrm{YR} 3 / 4$ & 10YR5/4 & SC & ma & sst.spl.fr.h & \\
\hline
\end{tabular}

a according to FAO (2006); ' $\mathrm{c}$ —clear; s—smooth; d—diffuse; a—abrupt; w—wavy; 'SC—Sandy clay; SL—Sandy loam; SCL—Sandy clay loam; CL—clay

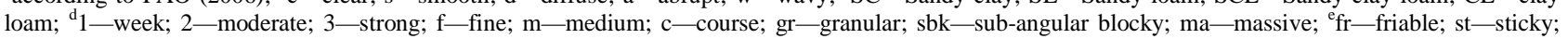
$\mathrm{pl}_{0}$ — non plastic; pl—plastic; sst—slightly sticky; spl—slightly plastic; sfr—slightly friable; sh—slightly hard; h—hard.

The horizon succession of profile IV was defined as A-C. This means that the profile had no diagnostic subsurface horizons and low pedogenetic development.

Therefore, morphological features of the profile at lower piedmont were not sufficient enough to define other soil order except Entisols (young soils) and categorized into great group and sub group levels as Udifluvents and Typic Udifluvents respectively [23] and Chromi-Dystric fluvisols [24].

\subsection{Soil Physical Properties}

Sand content ranged from $38 \%$ to $73 \%$, silt content from $7 \%$ to $30 \%$, and clay from $17 \%$ to $36 \%$ in profiles. The textural class of the soils was varied between loamy sand and clay loam. Soils of all profiles had higher sand content than that of silt and clay contents. According to Brammer [5], sand is the dominant particle in the hill soils and they developed from sandstone parent materials.

Table 2 also showed that clay content was relatively higher in different horizons of profile IV as compared to that of other forest sites. This is because of more clay deposition in this site through the processes of transportation and colluviation rather than weathering from the adjacent hilly areas. The clay content was found to be lower in the A1 horizons and increased downward for all soils. The downward increase of clay content could be explained by the translocation of finer clay particles throughout the profiles.

Bulk density values of the soils ranged from 1.15 to $1.32 \mathrm{Mg} \cdot \mathrm{m}^{-3}$. Bulk density is higher in subsurface horizons than the surface horizons (Table 2). The results of the present study is in consistent with the findings of Lee et al. [25] who observed an increase in soil bulk density with soil depth in a Malaysian tropical secondary forests.

Profile I showed the highest bulk density and Profile IV had the lowest bulk density in profile samples (Table 2) and in both surface and subsurface soils (Table 5).

The higher values of bulk density in soils might be contributed to low clay and high sand content as well as low amount of organic carbon [26]. Harris et al. [27] mentioned that soil quality decreased with increasing bulk density.

\subsection{Soil Chemical Properties}

Organic carbon (OC) contents of the soils ranged from 0.26 lower horizon of profile I to $1.73 \%$ in surface horizon of profile IV and declined with depth (Table 3). The piedmont soils (profile III and profile IV) contained somewhat higher amount of organic carbon compared to the hill top soils (profile I and profile II). The organic 
Table 5. Variance analysis of some soil properties with profile sites and depths.

\begin{tabular}{|c|c|c|c|c|c|c|c|c|c|c|c|}
\hline \multirow{2}{*}{ Soil depth } & \multirow{2}{*}{ OC (\%) } & \multirow{2}{*}{$\mathrm{pH}_{\mathrm{H}_{2} \mathrm{O}}$} & \multirow{2}{*}{$\mathbf{p H}_{\mathrm{KCl}}$} & \multirow{2}{*}{ Clay (\%) } & \multirow{2}{*}{$\begin{array}{c}\text { BD } \\
\left(\mathbf{M g} \cdot \mathbf{m}^{-3}\right)\end{array}$} & \multirow{2}{*}{$\begin{array}{l}\text { PBS } \\
(\%)\end{array}$} & CEC & Ex. $\mathbf{A l}^{3+}$ & ECEC & \multirow{2}{*}{ Als (\%) } & \multirow{2}{*}{ 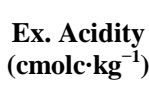 } \\
\hline & & & & & & & \multicolumn{3}{|c|}{${\text { cmolc } \cdot \mathrm{kg}^{-1}}^{-1}$} & & \\
\hline \multicolumn{12}{|c|}{ Profile I (Typic Haplustults) } \\
\hline Surface & 1.13 & 5.10 & 3.96 & 21 & 1.26 & 28.6 & 10.45 & 0.65 & 4.48 & 15.07 & 1.11 \\
\hline Subsurface & 0.41 & 4.86 & 3.84 & 28 & 1.28 & 18.4 & 9.37 & 0.65 & 2.87 & 22.65 & 1.15 \\
\hline \multicolumn{12}{|c|}{ Profile II (Typic Haplustults) } \\
\hline Surface & 1.54 & 5.16 & 4.15 & 29 & 1.22 & 32.7 & 11.8 & 0.54 & 4.78 & 11.30 & 0.92 \\
\hline Subsurface & 0.54 & 4.91 & 4.10 & 36 & 1.23 & 23.0 & 9.54 & 0.61 & 3.29 & 18.54 & 1.10 \\
\hline \multicolumn{12}{|c|}{ Profile III (Typic Dystrochrepts) } \\
\hline Surface & 1.61 & 5.17 & 4.23 & 17 & 1.18 & 32.5 & 10.8 & 0.48 & 4.4 & 10.91 & 0.89 \\
\hline Subsurface & 1.36 & 5.12 & 4.59 & 21 & 1.21 & 29.8 & 9.67 & 0.52 & 3.82 & 13.07 & 0.94 \\
\hline \multicolumn{12}{|c|}{ Profile IV (Typic Udifluvents) } \\
\hline Surface & 1.73 & 5.52 & 4.90 & 32 & 1.16 & 33.4 & 14.5 & 0.41 & 5.59 & 7.33 & 0.74 \\
\hline Subsurface & 1.45 & 5.23 & 4.70 & 35 & 1.15 & 31.7 & 10.12 & 0.44 & 4.06 & 12.12 & 0.85 \\
\hline Site & $* * *$ & ** & $*$ & *** & ${ }^{* * *}$ & ** & * & $* * *$ & $* * *$ & * & $* *$ \\
\hline Depth & $* * *$ & ** & NS & ** & ** & $* * *$ & $* * *$ & NS & *** & $*$ & NS \\
\hline Site $\times$ Depth & $* * *$ & NS & NS & NS & NS & NS & NS & NS & ** & NS & NS \\
\hline
\end{tabular}

Asterisks indicate significant effects according to ANOVA: ${ }^{*}, \mathrm{p}<0.05 ;{ }^{* *}, \mathrm{p}<0.01 ;{ }^{* * *}, \mathrm{p}<0.001$; NS, Not significant.

carbon content was found to be low in hill forest soils of Bangladesh. Soils of Bangladesh are particularly low in organic matter content with most values below 1\% [28] with a mean of $2.13 \%$ [29].

Organic carbon content was generally lower in Profile I than that of other three sites in both surface and subsurface soils (Table 5).

The lower content of organic carbon in the soils of studied area might be due to rapid mineralization of organic matter that was enhanced by favourable temperature and high rainfall. The organic carbon content (litter accumulation on surface soils) may be related to the abundance of vegetation, topographic variation and slope gradient of land. The piedmont soils had more organic carbon content. This was probably due to a considerable portion of organic matter accumulated on piedmont soils through moving down from the nearby hilly areas.

$\mathrm{pH}_{\mathrm{H}_{2} \mathrm{O}}$ values ranged from 4.44 to 5.52 and $\mathrm{pH}_{\mathrm{KCl}}$ from 3.57 to 4.90 in $\mathrm{C}$ horizon of profile I and in A1 horizon of profile IV respectively (Table 3 ) and all of the soils under study were categorizes as acidic in nature.

The acidity recorded on these soils might be as a result of the acidic nature of the parent rock coupled intensive leaching of bases.

The soil $\mathrm{pH}$ values tended to decrease with depth. The higher $\mathrm{pH}$ values at the surface layer across the study sites corresponded to the larger amounts of organic matter in the topsoil since all the sites were covered with trees. The release of exchangeable bases from organic matter through litter decomposition was responsible for higher $\mathrm{pH}$ in surface soils. This result is in agreement with the findings of Gafur et al. [30] who found the decreasing trend of $\mathrm{pH}$ with depth in soils of different profiles in Chittagong Hill Tracts of Bangladesh.

Soils of profile I showed the lowest values of $\mathrm{pH}_{\mathrm{H}_{2} \mathrm{O}}$ and $\mathrm{pH}_{\mathrm{KCl}}$ (Tables 3 and 5). The acidification was the result of a rather acidic parent material, assisted by strong biological activity and leaching, and substantial surplus precipitation in Chittagong Hill Tract, Bangladesh [31,32].

Table 3 showed that exchangeable $\mathrm{Ca}^{2+}, \mathrm{Mg}^{2+}, \mathrm{K}^{+}$and $\mathrm{Na}^{+}$, ranged from 0.98 (profile I) to 2.17 (profile IV) cmolc $\cdot \mathrm{kg}^{-1}, 0.19$ (profile I) to 1.46 (profile IV) cmolc $\cdot \mathrm{kg}^{-1}$, 0.17 (profile I) to 0.65 (profile IV) $\mathrm{cmolc}^{\circ} \mathrm{kg}^{-1}$ and 0.06 (profile I) to 0.57 (profile IV) cmolc $\cdot \mathrm{kg}^{-1}$ respectively. The exchangeable bases declined with depth in all the profiles under study (Table 3). Such results are in agreement with the observations of Akbar et al. [33], who found that total bases (sum of exchangeable $\mathrm{Mg}, \mathrm{Ca}, \mathrm{K}$ and $\mathrm{Na}$ ) in the soils decreased with depth. Exchangeable bases in soils were found to be higher in Profile IV and lower in Profile I (Table 5).

The higher concentration of exchangeable bases at the surface layer was probably due to the contribution of organic matter supplied from the vegetation. Akbar et al. [33] stated that higher contents of $\mathrm{Ca}$ and $\mathrm{Mg}$ in the surface horizons were probably associated with biological accumulation from plants.

In general, the values of exchangeable cations were higher in the soils at the piedmont sites (profile III and 
profile IV) as compared to the hill top sites (profile I and profile II). This might be due to higher losses of exchangeable cations in the soils of the hill top sites under study by extreme leaching and/or runoff processes. High rainfall and coarse texture of the soil probably favoured the intensive leaching of the basic cations. Higher topography also accelerates more cation losses from the soil. Lower piedmont soil (profile IV) was enriched by base cations from nearby outer sites through surface runoff.

Percent base saturation ranged from 11.8 (bottom soils of profile I) to $33.4 \%$ (topsoil of profile IV). Exchangeable bases contents (e.g. Ca, Mg, $\mathrm{K}$ and $\mathrm{Na}$ ) are relatively low in all pedons under study resulting in low base saturation. Base saturation in the soils decreased consistently with depth (Table 3).

Exchangeable bases were low, resulting in a low base saturation, which reflects the strongly weathered nature of the soils. Low base saturation is a characteristic of forest soils, and forest soils typically have relatively low $\mathrm{pH}$ values.

Like exchangeable bases, higher content of percent base saturation in soils was observed in Profile IV and lower in Profile I (Table 5).

The variation in base saturation reflects the intensity of leaching of bases and soil erosion. Yatnoa and Zauyahb [34] stated that the high base saturation values corresponded with the amounts of basic cations, especially $\mathrm{Ca}$ content. Base saturation is also related to soil acidity.

The CEC values ranged from $9.12 \mathrm{cmolc} \cdot \mathrm{kg}^{-1}$ at the lower depth of profile I to $14.5 \mathrm{cmolc} \cdot \mathrm{kg}^{-1}$ at the surface soil of profile IV. CEC values of profile I and Profile II showed increasing trends with depth, while, the values in profile III and profile IV showed decreasing trends with depth (Table 3). Higher CEC in surface soil might be due to higher amount of organic carbon in surface layers.

These results are in agreement with the findings of Kumar and Verma [35]. However, profile I and profile II had higher CEC in the subsurface than surface soil. This may be due to soil erosion [33].

Profile IV contained highest contents of CEC in surface and subsurface soils (Table 5).

CEC content might be related to the soil texture, clay mineralogical composition, and accumulation of organic matter [36] and degree of erosion.

The CEC was low in the soils under study. Because the soils were sandy textured and dominated mainly by kaolinite $[37,38]$.

The exchangeable $\mathrm{Al}$ concentration ranged from 0.41 cmolc $\cdot \mathrm{kg}^{-1}$ in surface soil of profile IV to $0.66 \mathrm{cmolc} \cdot \mathrm{kg}^{-1}$ in lower soil of profile I (Table 3). Table 5 showed that lower concentration of exchangeable $\mathrm{Al}$ was recorded in the surface and subsurface soils of profile IV (Typic Udifluvents) while higher concentrations of exchangeable $\mathrm{Al}$ was found in Profile I (Typic Haplustults). The result is in agreement with the findings of Dhananjaya and Ananthanarayana [39] who observed the exchangeable $\mathrm{Al}$ value in Ultisols and Entisols were 0.40 and 0.20 cmolc $\cdot \mathrm{kg}^{-1}$ respectively.

Highest contents of exchangeable $\mathrm{Al}$ in surface and subsurface soils of Profile I (Table 5) were closely related to lower soil $\mathrm{pH}$ [40], and clay [41-43] and advanced stage of weathering [44].

Exchangeable $\mathrm{Al}$ in Table 3 showed the increasing trends with profile depth. The lower concentration of exchangeable $\mathrm{Al}$ in the surface soil was probably due to a greater portion of $\mathrm{Al}$ bound in organic matter. Jansen et al. [45] stated that the complexation of Al with organic matter was known as a major mechanism for its mobility in forest soils.

The absolute value of 1 cmolc $\cdot \mathrm{kg}^{-1}$ for exchangeable $\mathrm{Al}$ in the soil solution leads to develop $\mathrm{Al}$ toxicity in soil $[11,46]$. Brix [47] reported that excess $\mathrm{Al}^{3+}$ in the soil solution interfered with root growth and function, as well as restricting plant uptake of certain nutrients, namely, $\mathrm{Ca}^{2+}$ and $\mathrm{Mg}^{2+}$. However, exchangeable $\mathrm{Al}$ concentration in all the soils under present investigation was below the above toxic value.

The effective cation exchange capacity (ECEC) varied from 1.96 cmolc $\cdot \mathrm{kg}^{-1}$ at the bottom horizon of profile IV to $4.78 \mathrm{cmolc} \cdot \mathrm{kg}^{-1}$ at surface horizon of profile II (Table 3 ). The values of ECEC might be attributed to the degree of weathering and leaching processes [48], clay content, type of clay minerals, parent material and exchangeable bases [39]. ECEC was relatively higher at the surface soil horizon and found to be decreased with depth (Table 3). Such decreasing phenomena with depth seemed to be affected mostly by the exchangeable bases rather than exchangeable acidity of soils under study.

Percent aluminum saturation in soil under study showed an increasing trend with depth and ranged from 13.39\% to $24.81 \%$ in profile I, $11.30 \%$ to $19.94 \%$ in profile II, $10.91 \%$ to $16.87 \%$ in profile III and $7.33 \%$ to $16.85 \%$ in profile IV. Aluminum saturation can be used as an indicator for Al toxicity in the soil solution [49,50]. Both surface and subsurface soils of profile I contained highest values of Percent aluminum saturation while the profile IV had the lowest.

It is evident that value of $\mathrm{Al}$ saturation is directly associated with exchangeable $\mathrm{Al}$ in acidic soils. High in exchangeable $\mathrm{Al}$ results in high level of $\mathrm{Al}$ saturation. Setiyono and Supardi [51] reported that the symptoms of $\mathrm{Al}$ toxicity were observed already at $30 \%$ of $\mathrm{Al}$ saturation. According to the findings, the contents of Al saturation were found to be low in soils of studied area. Dierolf et al. [52] stated that over $80 \% \mathrm{Al}$ saturation is required to impair growth of very tolerant crops.

Exchangeable acidity level ranged from 0.74 at surface soil of Profile IV to 1.25 at lower depth of Profile I. The 
value of exchangeable acidity was found to be increased with depth (Table 3).

Exchangeable acidity followed the similar distribution pattern of exchangeable Al. Exchangeable acidity created predominantly by $\mathrm{Al}$ ions [53]. The exchangeable acidity in the soils in the forest soils was considerably lower as the value of exchangeable Al was low. Dalovic [53] also found the mean value of the total exchangeable acidity was 3.39 cmolc $\cdot \mathrm{kg}^{-1}$ in forest soil. The least acidity recorded on soils of profile IV, might be as a result of the higher soil $\mathrm{pH}$ and organic matter and initial stage of weathering (Tables 3 and 5).

Analysis of variance (ANOVA) in Table 5 showed that sites significantly influenced all of the studied physico-chemical properties while soil depth had the significant influence on the most variables except $\mathrm{pH}_{\mathrm{KCl}}$, Ex. Al and Ex. Acidity. The result of ANOVA also revealed that sites effect seemed to be more effective due to variation in parent material, topography and land cover. The results obtained from this study are in agreement with the findings reported by other researchers [54]. They observed that soil physical and chemical properties showed variability as a result of variations in environmental factors such as climate, parent material, topography and land cover/land use. The interactive effects of sites and soil depths were significant to OC and ECEC.

\section{Conclusions}

The results of this study showed that matured soils were developed on the hill top while more young soils formed on the piedmont sites. Topographic variation associated with leaching, soil erosion and deposition affected the morphological, physical and chemical characteristics of studied soils to a greater extent. The soil properties in terms of morphology, physical and chemical characteristics as well as other features like leaching condition and soil erosion should be taken into consideration for appropriate establishment of plantation or afforestation programs in the soils of hilly regions under study.

Therefore, some measurements may be recommended to improve soil physicochemical properties of soils in hilly regions under study. For example, contour plantation, inter-cropping, use of cover crops and use of mulches should be necessary to protect the soils. Such measurements resulted in a higher amount of organic matter, reduced erosion and increased water holding capacity in the soils under investigation.

\section{REFERENCES}

[1] P. W. Birkeland, "Soil and Geomorphology," Oxford University Press, New York, 1999, p. 430.

[2] A. Yair, "The Role of Topography and Surface Cover upon Soil Formation along Hill Slopes in Arid Climates,”
Geomorphology, Vol. 3, No. 3-4, 1990, pp. 287-299. http://dx.doi.org/10.1016/0169-555X(90)90008-E

[3] R. H. Dahlgren, J. L. Boettinger, G. L. Huntington and R. G. Amundson, "Soil Development along an Elevational Transect in the Western Sierra Nevada, California," Geoderma, Vol. 78, No. 3-4, 1997, pp. 207-236. http://dx.doi.org/10.1016/S0016-7061(97)00034-7

[4] Y. Canton, A. S. Bent and R. Lazaro, "Soil-Geomorphology Relations in Gypsiferour Materials of the Tabernas Desert,” Geoderma, Vol. 115, No. 3-4, 2003, pp. 193222. http://dx.doi.org/10.1016/S0016-7061(03)00012-0

[5] H. Brammer, "Bangladesh Land Resources Technical Report-3,” AGL: SF, Pak-6, FAO, Rome, 1971.

[6] Reconnaissance Soil Survey, "Reconnaissance Soil Survey of Sadar South and Cox's Bazar Subdivision Chittagong District,” Department of Soil Survey, Government of the Peoples Republic of Bangladesh, 1976, p. 5.

[7] W. J. Vreeken, "Soil Variability in Small Loess Watersheds: Clay and Organic Matter Content," Catena, Vol. 1, 1973, pp. 18l-195. http://dx.doi.org/10.1016/S0341-8162(73)80010-4

[8] P. Sollins, C. C. Grier, F. M. McCorison, K. Cromack and D. Fogel, "The Internal Nutrient Budget of an Old Growth Douglas-Fir Ecosystem in Western Oregon,” Ecological Monographs, Vol. 50, 1980, pp. 261-285.

http://dx.doi.org/10.2307/2937252

[9] G. M. Pierzynski, J. T. Sims and G. F. Vance, "Soils and Environmental Quality,” CRC Press LLC, USA, 2000.

[10] M. J. Singer and D. N. Munns, "Soils: An Introduction," Prentice-Hall Inc., New Jersey, 1996, p. 270.

[11] M. Jakovljevic, M. Kresovic, S. Blagojevic and S. Antic-Mladenovic, "Some Negative Chemical Properties of Acid Soils," Journal of the Serbian Chemical Society, Vol. 70, No. 5, 2005, pp. 765-774. http://dx.doi.org/10.2298/JSC0505765J

[12] J. P. Boudot, T. Becquer, D. Merlet and J. Rouiller, "Aluminium Toxicity in Declining Forests: A General Overview with a Seasonal Assessment in a Silver Fir Forest in the Vosges Mountains (France)," Annals of Forest Science, Vol. 51, No. 1, 1994, pp. 27-51.

http://dx.doi.org/10.1051/forest:19940103

[13] G. Sposito, “The Environmetal Chemistry of Aluminium,” CRC Press LLC, USA, 1996.

[14] C. Gauthier, "Contribution to the Study of Fractionation of Free Aluminium in Solutions of Forest Soils. Influence of Quality and Nature of Organic Matter,” Faculté des Sciences et Techniques, Université de Limoges, 2002, p. 156.

[15] A. Van Wambeke, "Soil Moisture and Temperature Regimes of Asia," Soil Conservation Service, USDA, SMSS Technical Monograph, No. 9, Washington DC, 1985.

[16] Soil Survey Staff, “Keys to Soil Taxonomy,” SMS Technical Monograph, No. 436, 1990.

[17] FAO, "Guidelines for Soil Description," 4th Edition, FAO, Rome, 2006.

[18] P. R. Day, "Particle Fraction and Particle Size Analysis," In: C. A. Black, Ed., Methods of Soil Analysis, Part 1, 
American Society of Agronomy, Madison, 1965, pp. 545567.

[19] C. A. Black, "Methods of Soil Analysis,” American Society of Agronomy, Inc. Publisher, Madison, 1965, pp. 894-895.

[20] A. Walkley and I. A. Black, "An Examination of the Degtjareff Method for Determining Soil Organic Matter and a Proposed Modification of the Chromic Acid Titration Method," Soil Science, Vol. 37, No. 1, 1934, pp. 2938. http://dx.doi.org/10.1097/00010694-193401000-00003

[21] Minitab Inc., “Minitab User’s Guide, Release 11,” Minitab, State College, 1996, p. 216.

[22] S. W. Boul and F. D. Hole, "Clay Skin Genesis in Wisconsin Soils," Soil Science Society of America, Vol. 25, No. 5, 1961, pp. 377-379. http://dx.doi.org/10.2136/sssaj1961.03615995002500050 $\underline{021 x}$

[23] Soil Survey Staff, "Soil Taxonomy," A Basic of Soil Classification for Making and Interpreting Soil Survey, USDA Handbook No. 436, Washington DC, 1999.

[24] FAO/ISRIC, "World References Base for Soil Resources," World Soil Report, 2006, Rome, p. 128.

[25] Y. L. Lee, H. A. Osumanu, M. Nik Muhamad Ab and M. B. Jalloh, "Organic Matter, Carbon and Humic Acids in Rehabilitated and Secondary Forest Soils," American Journal of Applied Sciences, Vol. 6, No. 5, 2009, pp. 824-828.

[26] R. D. Gupta, S. Arora, G. D. Gupta and N. M. Sumberia, "Soil Physical Variability in Relation to Soil Erodibility under Different Land Uses in Foothills of Siwaliks in N-W India,” Tropical Ecology, Vol. 51, No. 2, 2010, pp. 183-197.

[27] R. F. Harris, D. L. Karlen and D. J. Mulla, “A Conceptual Framework for Assessment and Management of Soil Quality and Soil Health,” In: J. W. Doran and A. J. Jones, Eds., Methods for Assessing Soil Quality, SSSA Special Publication 49, Madison, 1996, pp. 61-82.

[28] BARC, "Fertiliser Recommendation Guide for Most Bangladesh Crops,” Dhaka, Bangladesh Agricultural Research Council, 1985.

[29] M. S. H. Chowdhury, S. Biswas, S. M. S. Haque, N. Muhammed and M. Koike, "Comparative Analysis of Some Selected Macronutrients of Soil Orange Orchard and Degraded Forests in Chittagong Hill Tracts, Bangladesh,” Journal of Forest Research, Vol. 18, No. 1, 2007, pp. 2730. http://dx.doi.org/10.1007/s11676-007-0005-0

[30] A. Gafur, C. B. Koch and O. K. Borsgaard, "Weathering Intensity Controlling Sustainability of Ultisols under Shifting Cultivation in the Chittagong Hill Tracts of Bangladesh,” Soil Science, Vol. 169, No. 9, 2004, pp. 663-674. http://dx.doi.org/10.1097/01.ss.0000142632.80160.5b

[31] A. Gafur, O. K. Borggaard, J. R. Jensen and L. Petersen, "Changes in Soil Nutrient Content under Shifting Cultivation in the Chittagong Hill Tracts of Bangladesh," Danish Journal of Geography, Vol. 100, No. 1, 2000, pp. 37-46. http://dx.doi.org/10.1080/00167223.2000.10649437

[32] A. Gafur, J. R. Jensen, O. K. Borggaard and L. Petersen, "Runoff and Losses of Soil and Nutrients from Small
Watersheds under Shifting Cultivation (Jhum) in the Chittagong Hill Tracts of Bangladesh," Journal of Hydrology, Vol. 279, 2003, pp. 293-309.

[33] M. H. Akbar, O. H. Ahmed, A. S. Jamaluddin, N. M. Nik Ab. Majid, H. Abdul-Hamid, S. Jusop, A. Hassan, K. H. Yusof and A. Abdu, "Differences in Soil Physical and Chemical Properties of Rehabilitated and Secondary Forests," American Journal of Applied Sciences, Vol. 7, No. 9, 2010, pp. 1200-1209.

http://dx.doi.org/10.3844/ajassp.2010.1200.1209

[34] E. Yatnoa and S. Zauyahb, "Properties and Management Implications of Soils Formed from Volcanic Materials in Lembang Area, West Java," Indonesian Journal of Agricultural Science, Vol. 9, No. 2, 2008, pp. 44-54.

[35] P. Kumar and T. S. Verma, "Characterization and Classification of Some Rice Growing Soils of Pal am Valley of Himachal Pradesh,” Agropedology, Vol. 15, No. 2, 2005, pp. 80-85.

[36] S. Shoji, Y. Fujiwara, I. Yamada and M. Saigusa, "Chemistry and Clay Mineralogy of Ando Soils, Brown Forest Soils, and Podzole Soils Formed from Recent Towada Ashes, Northeastern, Japan,” Soil Science, Vol. 133, No. 2, 1982, pp. 69-86. http://dx.doi.org/10.1097/00010694-198202000-00001

[37] M. M. Hassan, "Clay Mineralogy of Some Soils Developed on Alluvial Parent Materials in Bangladesh,” Journal of Bangladesh Academy of Sciences, Vol. 15, 1991, pp. 163-171.

[38] M. L. Alam, N. Miyauchi and A. Shinagawa, "Study on Clay Mineralogical Characteristics of Hill and Terrace Soils of Bangladesh,” Clay Science, Vol. 9, 1993, pp. 109-121.

[39] B. C. Dhananjaya and R. Ananthanarayana, "Soil Acidity and Exchange Chemistry in Soils of Southern Karnataka," Agropedology, Vol. 19, No. 2, 2009, pp. 99-105.

[40] L. Mladkova, L. Boruvka and O. Drabek, "Distribution of Aluminium among Its Mobilizable Forms in Soils of the Jizera Mountains Region,” Plant, Soil and Environment, Vol. 50, No. 8, 2004, pp. 346-351.

[41] K. A. Shade, "Temporal Analysis of Floodplain Deposition Using Urban Pollution Stratigraphy,” Wilson's Creek, SW Missouri, Master's Thesis, Southwest Missouri State University, 2003.

[42] W. E. Rodgers, "Mercury Contamination of Channel and Floodplain Sediments in Wilson's Creek Watershed,” Southwest Missouri, Master's Thesis, Southwest Missouri State University, 2005.

[43] D. Hattori, J. Sabang, S. Tanaka, J. J. Kendawang and I. Ninomiya, "Soil Characteristics under Three Vegetation Types Associated with Shifting Cultivation in a Mixed Dipterocarp Forest in Sarawak, Malaysia," Soil Science and Plant Nutrition, Vol. 51, No. 2, 2005, pp. 231-241. http://dx.doi.org/10.1111/j.1747-0765.2005.tb00027.x

[44] N. Tanskanen, "Aluminium Chemistry in Ploughed Podzolic Forest Soils,” Unpublished M. Sc. Dissertation, Department of Forest Ecology, Faculty of Agriculture and Forestry, University of Helsinki, Finland, 2006.

[45] B. Jansen, K. G. J. Nierop and J. M. Verstraten, "Me- 
chanisms of Controlling the Mobility of Dissolved Organic Matter, Aluminium and Iron in Podzol B Horizons," European Journal of Soil Science, Vol. 56, No. 4, 2005, pp. 537-550.

http://dx.doi.org/10.1111/j.1365-2389.2004.00686.x

[46] A. Amberger, "Soil Fertility and Plant Nutrition in the Tropics and Subtropics," IFA/IPI, 2006, p. 96.

[47] H. Brix, "Soil Acidity,” 2008. Protocol_Soil_Acidity_20081103.doc.

[48] B. T. Kang, M. Gichuru, N. Hulugalle and N. J. Swift, "Soil Constraints for Sustainable Upland Crop Production in Humid West Africa," Proceedings of the International Symposium of Tropical Agriculture Research Centre, Tsukuba, 1991, pp. 101-112.

[49] E. Evans and E. J. Kamprath, "Lime Response as Related to Percent Al Saturation, Solution Al, and Organic Matter Content," Soil Science Society of America Proceedings, Vol. 34, No. 6, 1970, pp. 893-896. http://dx.doi.org/10.2136/sssaj1970.03615995003400060 $\underline{023 x}$

[50] R. H. Fox, "Soil pH, Aluminum Saturation and Corn Grain Yield,” Soil Science, Vol. 127, No. 6, 1979, pp. 330-335. http://dx.doi.org/10.1097/00010694-197906000-00002

[51] S. Setiyono and G. Supardi, "Liming Acid Mineral Soils in Indonesia as a Precondition to Increase N-Efficiency," In: B. T. Kang and J. van der Heide, Eds., Proceedings of the Symposium, Nitrogen Management in Farming Systems in Humid and Subhumid Tropics, Institute for Soil Fertility, Haren, 1985, pp. 185-198.

[52] T. Dierolf, T. Fairhurst and E. Mutert, "Soil Fertility Kit," GTZ-GmbH, FAO, PT Jasa Katom, and PPI and PPIC, Oxford Graphic Printer, 2001.

[53] I. G. Dalovic, S. Dorde, D. S. Jockovic, J. Goran, G. J. Dugalic, G. F. Bekavac, B. Purar, S. I. Seremesic and M. D. Jockovic, "Soil Acidity and Mobile Aluminum Status in Pseudogley Soils in the Cacak-Kraljevo Basin,” Journal of the Serbian Chemical Society, Vol. 77, No. 6, 2012, pp. 833-843. http://dx.doi.org/10.2298/JSC110629201D

[54] O. Dengiz, C. Gol, S. Karaca and M. Yuksel, "Effects of Different Landscape Position and Parent Material on Soil Variability and Land Use in both Sides of Acicay RiverCankır1," International Soil Meeting on Soil Sustaining Life on Earth, Managing Soil and Technology Proceedings, Sanliurfa, Vol. 2, 2006, pp. 745-751. 